\title{
Impact of Loyalty Cards On Customers' Store Loyalty
}

Elif Akagün Ergin, (E-mail: eakagun@cankaya.edu.tr), Çankaya University, Turkey Nurettin Parıltı, (E-mail: parilti@gazi.edu.tr), Gazi University, Turkey

Bülent Özsaçmacı,(E-mail: bozsacmaci@ cankaya.edu.tr), Çankaya University, Turkey

\begin{abstract}
In this paper, we try to determine whether loyalty cards issued by stores have an impact on customer loyalty and how loyalty cards compare with other factors companies can use to increase loyalty in general. Based on the results of the study, it is concluded that loyalty cards have no impact on customers's store loyalty. On the contrary, it is observed that customers that use their loyalty cards frequently tend to shop at different stores with different loyalty cards.
\end{abstract}

\section{INTRODUCTION}

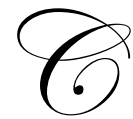

ompanies place a great emphasis on creating and maintaining customer loyalty. To this end, they use a variety of means to encourage loyalty. It is a known fact that customer retention is more important and more cost-effective than customer development. Loyalty is a positive belief in the value that a company provides, leading to increased purchases over time. Customer loyalty is described as the strength of the relationship between an individual's relative attitudes and repeat patronage (Dick and Basu, 1994). According to Customer Loyalty Research Center (2001), loyalty is "the commitment of customer to a particular brand or company".

There are more than 1 billion people enrolled in loyalty programs today (Capizzi and Ferguson, 2003). Multimerchant loyalty coalitions now exist in Canada, Argentina, Peru, Singapore, Poland, Germany, Australia, Malaysia, Thailand, Norway, Turkey, El Salvador and the Philippines, to list a few. Others will soon follow. For example, in Turkey, the Garanti Bank Bonus MasterCard loyalty program recently reached the 2 million threshold in members. This program now boasts 750 stores with over 18,000 outlets where cardholders can redeem Bonus points. Since the program launch in April 2000, Garanti claims that members have redeemed US \$22 million in cash value awards and US \$13 million in goods and services.

Loyalty programs have become one of the most critical means by which companies manage their customer relationships. The question is whether these loyalty programs really work. Can a loyalty program change how customers behave and get them to spend more money with a specific retailer? Can loyalty programs reduce the likelihood that customers will move their business to a main rival?

Card-based loyalty programs have been growing in popularity during the last decade (Karolefski, 1998). Loyalty cards have become part of most consumers' daily lives. Retailers have been doing their best to lure customers by offering them loyalty cards but the effectiveness and impact of these cards seem ambigious. What loyalty cards have actually delivered is often questioned. A major benefit of giving loyalty cards to customers is the collection of useful information about customer behavior that might be used for marketing decision-making(Cortinas et al., 2005). Loyalty cards also enable companies to customize their marketing mix varibles to the store or customer segment level.

Unfortunately, loyalty card usage and store loyalty may not always go hand-in-hand. Customers prefer to shop at different stores and use different loyalty cards. Most customers are multi-card holders because there are various available discounts and obtaining a loyalty card is quite simple. These customers believe that by shopping around and utilizing a range of store loyalty cards rather than one, they can save money and make greater financial gain (Davies, 1998). The critical question is how to find a way to give customers something valuable but also 
something so special that can not be quickly duplicated by competitors. The uniqueness must be a core benefit for the customer, in that case it will be less tempting for customers to switch to other retailers.

\section{PURPOSE OF THE STUDY}

Do customers choose to go to a specific store due to the loyalty cards they have or are there more pressing reasons for preferring that store? The main objective of this study is trying to determine an answer for this particular question. Therefore, we first examine the impact that loyalty cards have on customers' store loyalty. Second, we look at how loyalty cards compare with other factors companies can use to increase loyalty in general.

\section{RESEARCH DESIGN AND METHODOLOGY}

The study took place in Ankara, the capital city of Turkey with the participation of 309 turkish consumers. All of the respondents in the study were 18 years or older. A mall-intercept approach was adopted in the data collection A total of 309 surveys were conducted face-to-face at three selected shopping malls in a large metropolitan area. These malls were specifically selected because they had stores that do offer customer loyalty cards as well as those that do not. To avoid systematic biases, recruiters paid attention to selection criteria based on cross-cultural balance, gender, age distribution, day of week, and time of day.

The survey composed of 16 questions and was divided into two sections. In the first section, demographic items were included to obtain information regarding respondent's age, gender, education and income. These demographic variables helped to explain different consumption behaviors of different types of consumers. In the second section, items were asked regarding the concept of store loyalty cards and other factors that may have an effect on customers' store loyalty. Prior to conducting the field study, the validity of the survey questions was determined by a pilot study including 34 subjects.

\section{METHOD}

When all of the 309 surveys were compiled, the data was coded and entered. The coded data was sorted and analyzed by SPSS program. Chi-square analysis was used to examine the loyalty card use and store loyalty variables.

The following hypotheses were developed to be tested for this study.

$\mathbf{H}_{1}$ : $\quad$ Loyalty cards have an impact on customers' store loyalty.

H01: There is no relationship between store loyalty and age.

H02: There is no relationship between store loyalty and gender.

H03: There is no relationship between store loyalty and income level.

H04: There is no relationship between the frequency of loyalty card usage and age.

H05: There is no relationship between the frequency of loyalty card usage and gender.

H06: There is no relationship between the frequency of loyalty card usage and income level.

\section{FINDINGS OF THE RESEARCH}

Allocation of Subjects According to Age Groups

\begin{tabular}{|c|c|c|}
\hline Age Groups & Number of Respondents & \% Value \\
\hline $18-24$ & 56 & 18,2 \\
\hline $25-29$ & 60 & 21,4 \\
\hline $30-34$ & 65 & 24,9 \\
\hline $35-39$ & 77 & 16,4 \\
\hline 40 and older & 51 & 100,0 \\
\hline Total & 309 & \\
\hline
\end{tabular}


In the study, age categories have been divided into 5 groups. Based on this, 18,2 percent of the subjects are in 18-24 age group, the 19,4 percent of the subjects are in 25-29 age group, the 21,1 percent of the subjects are in 3034 age group, 24,9 percent of the subjects are in 35-39 age group, and finally the 16,4 percent of the subjects are in 40 and older age group.

\section{Allocation Of Subjects According To Gender}

\begin{tabular}{|c|c|c|}
\hline Gender & Number of Respondents & \% Value \\
\hline Female & 174 & 56,3 \\
\hline Male & 135 & 43,7 \\
\hline Total & 309 & 100,0 \\
\hline
\end{tabular}

According to the gender results, 56,3 percent of the 309 respondents were female customers and 43,7 percent of the respondents were male customers.

\section{Allocation Of Subjects According To Education Level}

\begin{tabular}{|c|c|c|}
\hline Education Level & Number of Respondents & \% Value \\
\hline Elementary School Graduate & 12 & 3,9 \\
\hline High School Graduate & 116 & 37,5 \\
\hline University Graduate & 124 & 40,1 \\
\hline Master/Ph.D. Degree & 57 & 18,4 \\
\hline Total & 309 & 100,0 \\
\hline
\end{tabular}

Based on educational levels, results indicate that more than half of the respondents $(\% 58,5)$ have a university and/ or graduate degree. The remaining 37,5 percent have graduated from high school and 3,9 have an elementary school diploma. Since this study was conducted in a large metropolitan city, an overwhelming majority of the repondents have a higher education background.

\section{Allocation Of Subjects According To The Frequency Of Loyalty Card Usage}

\begin{tabular}{|c|c|c|}
\hline Frequency of Loyalty Card Usage & Number of Respondents & \% Value \\
\hline Everyday & 65 & 42,7 \\
\hline 2-3 times a week & 132 & 13,3 \\
\hline Once a week & 41 & 18,4 \\
\hline Once every two weeks & 57 & 4,5 \\
\hline Once a month & 14 & 100,0 \\
\hline Total & 309 & \\
\hline
\end{tabular}

According to the frequency of loyalty card usage, 21 percent of the customers in the study claim they use their loyalty cards every single day, whereas almost 43 percent use it 2-3 times a week. 13,3 percent take advantage of their loyalty cards once a week, and 18,4 percent state they use their cards once every two weeks. The remaining 4,5 percent use their loyalty cards once a month. 


\section{ALLOCATION OF LOYALTY CARDS BASED ON THEIR BENEFITS}

\begin{tabular}{|c|c|c|c|c|c|}
\hline \multirow{2}{*}{ Benefits of Loyalty Cards } & \multicolumn{5}{|c|}{ Ranking \% } \\
\hline & 1 & 2 & 3 & 4 & 5 \\
\hline Providing discounts in specified time periods & 65,6 & 8,4 & 5,9 & 7,9 & 12,2 \\
\hline Notifying cardholders about upcoming promotions/discounts & 42,7 & 33,3 & 7,8 & 3,9 & 12,3 \\
\hline Special discounts on cardholder's special days & 12,3 & 4,5 & 61,6 & 12,6 & 9,0 \\
\hline Providing an assortment of prizes & 31,7 & 23,3 & 12,4 & 5,4 & 27,2 \\
\hline Providing cash awards/gift certificates & 24,6 & 22,0 & 3,9 & 17,8 & 31,7 \\
\hline
\end{tabular}

When the respondent customers in the study were asked to rank the importance of benefits they get from their loyalty cards, 65,6 percent identified receving discounts in specific time periods as the most important benefit the loyalty card provides them. 42,7 percent stated that being notified about upcoming discounts/ promotions in the store was a major benefit of the loyalty cards. 31,7 and 24,6 percent of the customers listed receiving an assortment of prizes and gift certificates as a major benefit respectively.

\section{Allocation of Factors that May Impact Store Loyalty}

\begin{tabular}{|l|c|c|c|c|c|c|c|c|c|c|}
\hline $\begin{array}{l}\text { Allocation of Factors That } \\
\text { May Impact Store Loyalty }\end{array}$ & $\mathbf{1}$ & $\mathbf{2}$ & $\mathbf{3}$ & $\mathbf{4}$ & $\mathbf{5}$ & $\mathbf{6}$ & $\mathbf{7}$ & $\mathbf{8}$ & $\mathbf{9}$ & $\mathbf{1 0}$ \\
\hline Transportaion Convenience & 25,8 & 7,5 & 11,8 & 8,1 & 10,9 & 11.8 & 13,4 & 5,4 & 2,2 & 3,1 \\
\hline Parking Availability & 22,1 & 11,2 & 8,9 & 15,6 & 8,5 & 11,1 & 9,3 & 3,4 & 5,2 & 4,7 \\
\hline Store Hours of Operation & 18,8 & 3,7 & 3,7 & 14,7 & 6,2 & 14,8 & 13,6 & 10,4 & 7,6 & 6,5 \\
\hline Quality of Products & 23,4 & 18,4 & 7,4 & 8,1 & 12,4 & 8,1 & 11,9 & 3,1 & 4,2 & 3,0 \\
\hline $\begin{array}{l}\text { Sufficient Numer of } \\
\text { Salespeople }\end{array}$ & 21,2 & 4,7 & 6,3 & 5,9 & 8,1 & 5,1 & 9,7 & 17,6 & 9,8 & 11,6 \\
\hline Ease of Product Return & 15,3 & 15,3 & 6,9 & 9,7 & 19,9 & 7,5 & 11,5 & 6,7 & 3,5 & 3,7 \\
\hline $\begin{array}{l}\text { Store's Attractive Interior } \\
\text { Design }\end{array}$ & 14,5 & 10,3 & 17,7 & 1,4 & 7,5 & 3,5 & 14,5 & 17,8 & 5,6 & 7,2 \\
\hline $\begin{array}{l}\text { Availability of Assortment } \\
\text { of Products }\end{array}$ & 27,5 & 13,9 & 7,8 & 6,7 & 7,8 & 10,8 & 10,3 & 5,7 & 4,2 & 5,3 \\
\hline $\begin{array}{l}\text { Salespeople Attitude toward } \\
\text { Customers }\end{array}$ & 25,3 & 3,7 & 12,3 & 14,6 & 5,6 & 10,3 & 8,5 & 10,2 & 3,5 & 6,6 \\
\hline Store Security & 15,8 & 6,4 & 7,2 & 6,2 & 12,8 & 7,2 & 10,0 & 12,6 & 15,6 & 6,2 \\
\hline
\end{tabular}

When inquired about other factors that has an impact on store loyalty, consumers classified availability of a wide assortment of products, salespeople's positive attitudes and ease of transportation as their top factors. Quality of products and ample parking space were also mentioned among the factors that influence customer store loyalty.

\section{RESULTS}

The main hypothesis of this study centered on evaluating the impact loyalty cards have on customers' store loyalty. Based on the performed analysis, it is observed that the probability value $(\alpha=0,05)$ is smaller than the level of significance. Therefore, we reject $\mathbf{H 1}$ hypothesis and conclude that the most prominent finding of this research is that loyalty cards do not promote store loyalty. Frequent loyalty card users $(\% 63,7)$ were found to be less loyal.

For the analysis of $\mathbf{H ~} 01$ hypothesis, the probability value $(\alpha=0,05)$ is smaller than the level of significance. Thus, we reject $\mathbf{H} \mathbf{0 1}$ hypothesis and state that there is indeed a relationship between a customer's store loyalty and his/ her age. 
For H02 hypothesis, it is observed that the probability value $(\alpha=0,05)$ is greater than the level of significance. We accept this hypothesis and confirm that the gender of a customer has no influence on his/her store loyalty. On the other hand, $\mathbf{H 0 3}$ hypothesis is rejected because the analysis suggests that a customer's income level has an impact on store loyalty.

H04 hypothesis is also rejected since the probability value $(\alpha=0,05)$ is less than the level of significance. This indicates that a relationship exists between a customer's age and the frequency of loyalty card usage.

Both H05 and H06 hypotheses are accepted as their observed probability values exceed the level of significance. So, we see some evidence that neither the income level nor the gender of a customer has a relationship with the frequency of his/ her loyalty card usage.

\section{CONCLUSION}

This research aimed to identify whether loyalty cards issued by stores have an impact on customer loyalty and how loyalty cards compare with other factors companies can use to increase loyalty in general. Loyalty programs are found everywhere but their true value still remains vague in many cases. There is no doubt that the loyalty cards have certain benefits for managers as well as customers. Companies are able to gather some very useful information about their consumers and they benefit from this accumulated knowledge as they develop marketing strategies. By doing so, companies are able to segment their markets more effectively, serve their target markets more succesfully. However, many customers $(85,1 \%$ of our sample) complain about this fact and state that it is a rather disturbing and privacy invading matter that companies get their hands on such personal information.

$73,5 \%$ of the customers in this study confessed that having a loyalty card of a particular store does not prevent them from going to other retailers. Customers feel they benefit more by visiting a variety of stores and utilizing a range of cards. Then the important issue is what companies must do to make their cards a "truly loyal" one? There must be a unique benefit they provide to the consumer to keep them coming back to the same store over and over again, perhaps a cumulative reward system would do the trick. Another possibilty would be joining forces with other retailers. Multi-merchant loyalty coalitions are quite common in most countries including Turkey. Customers enjoy the assortment of benefits these different retailers provide. That is why these multi-merchant membership programs are getting bigger and more popular.

Loyalty cards are quite an important component in a whole program of efforts designed to increase customer commitment to a store. They represent the opportunity to build long term customer loyalty. But they are not the sole factor in a customer's store loyalty development. Results of this study show that customers also focus heavily on the availability of a wide assortment of products, salespeople's positive attitudes and ease of transportation as their top factors for developing store loyalty. Therefore, companies have to take the whole package into consideration. They must aim to build a connected network of customers, partners and vendors, enabled by technology, all working towards profitable, and mutually beneficial relationships.

\section{REFERENCES}

1. Ziliani, Cristina, Sophisticated Segmentation and Precise Targeting: Loyalty Cards in Italy, European Retail Digest, Issue 39, Autumn 2003.

2. Dick A. and Basu K., Customer Loyalty: Toward and Integrated Conceptual Framework, Journal of the Academy of Marketing Science, vol. 22, Spring 1994, pp. 99-113.

3. Bellizzi, J. A. and Bristol, T., An Assessment of Supermarket Loyalty Cards in One Major U.S. Market Journal of Consumer Marketing, Vol.21, No. 2, 2004, pp. 144-154.

4. Worthington, Steve, Loyalty Cards and the Revitalisation of the Town Centre, International Journal of Retail \& Distribution Management, Vol.26, No.2, 1998, pp.68-77.

5. Cortinas, M., Elorz, M., and Mugica, J. M., Loyalty Cards: Are Retailers Ignoring Non-Card Holder Behavior?, European Retail Digest, Issue 45, Spring 2005.

6. Capizzi, M.T. and Ferguson, R., Loyalty Trends for the 21st Century, Colloquytalk, 2003. 
7. Davies, Gill, Loyalty Cards Can Erode Loyalty. Only Customer Relationship Programs Can Build It, OXIRM, Issue 20, 1998, pp.8-13.

8. Cuthbertson, Richard, Loyalty Card Schemes in Retailing Across Europe, OXIRM, Issue 20, 1998, pp. 5-7.

9. Bank Technology News, Vol. 16, No. 10, October 2003.

10. Marketing Week, June 6, 2002.

11. www.chainstorage.com, feb. 2002.

\section{NOTES}

